\title{
DAMS IN TIME OF WATER NATIONALISM
}

\author{
Ciprian - Beniamin Benea, ${ }^{1}$ Adina Secară Onița ${ }^{2}$
}

\begin{abstract}
A dam, in most cases is a large, impressive concrete structure. A commanding number of large dams exist with over 45000 estimated in the world. It is important to understand such a concrete structure not only from a technical perspective, but also from the view of local community in the region of the dam. Also, it is important to know the international impact of a dam on a river basin and the measures necessary for implementing a dam, as well as the positive and negative effects of dam construction itself. Preliminary measures aim to characterize a river regarding natural, geological, geographical patterns, human geographical distribution, and food production. Prospective trends, such as the need for augmented water volumes for a water-fed agriculture, industrialization, energy, and river transportation, can influence decisions connected to dam building. Recently, climate change, a phenomenon considered as human-induced, at least partially, and the prospect of a water-stressed world, are another elements that affect decisions about build dams, especially regarding water security and green energy and a renewable resource under threat. This paper presents the main administrative requirements for a team involved in dam construction, including their specific tasks and interactions. The main aim of this paper is to establish political meaning of dams, and their capacity to influence economics, society, and the environment in an interconnected world.
\end{abstract}

JEL Classification Numbers: L94, O13, Q25; DOI: http://dx.doi.org/10.12955/cbup.v5.896

Keywords: dam, energy, environment, water

\section{Introduction}

A dam affects two vital and interrelated resources: water and food, with the latter depending on water availability. Water and human civilization are inseparable, especially in the light of the direct relationships between the evolution of human civilization and rivers. A dam is an engineering feat that helps humans control and influence nature but often interferes with the river's normal course, and at times creates adverse effects. Whereas in the past dams were built to prevent floods or were conceived as a component of an irrigation plan for providing water in drought-prone regions, the last century has witnessed dam construction for multiple purposes, from flood mitigation and water storage to energy generation, transport facilitation, recreational activities, and tourism. The hidden part of this story is that dams have been used as instruments to demonstrate national rise and power and as a means of political control upon minorities located in the region of the dam or in other states adjoining the river, known as 'riparian' countries, as defined by the Danube Commission. In these specific cases, dams have become instruments of foreign policy.

It is well known that water availability is a barrier to broader economic development. As mentioned by Chellaney (2013), water availability of less than $2000 \mathrm{~m}^{3}$ per person per annum results in little expansion for sustainable economic development and environmental protection. Rising powers that are geographically located to control the flow of the rivers onto other countries with riparian rights, regard dams as necessary instruments for political control. Their thinking is that where they can control water flowing onto other countries, the can influence their political and strategic decisions. Turkey and China are such states. For example, Syria and Iraq are potentially affected by Turkey's decision regarding the dam development program in south-western Anatolia. As well, China has domination over Tibet, which is named The Third Pole, because of the water that flows from its glaciers. In this respect, China can use dams and other schemes to control the flow of this water onto another 13 riparian countries, and thus influence these countries' behavior (Chellaney, 2013).

Nevertheless, before a dam is built, there are necessary specific steps to be taken, from the decision adopted at highest political level to creating administrative constituencies, and technical and administrative structures that operate the dam.

\section{Data and Methodology}

This study considered both positive and negative aspects, concentrating on features that define a dam, and the main steps involved in building one. The main sources are materialized in books covering subjects connected to water, agriculture, energy, sustainable development, diplomacy and geopolitics,

\footnotetext{
${ }^{1}$ University of Oradea, Faculty of Economics; c_benea@yahoo.com

${ }^{2}$ University of Oradea, Faculty of Economics; ooadina@yahoo.com
} 
and climate changes, while the part of the paper regarding the actual construction of a dam results from direct researching the way some dams were built. Iron Gate System built on Danube River fits perfectly this category. The method used for writing this paper is both descriptive and the comparative, with comparative method being used especially when there are analyzed positive and negative aspects of dams' construction.

\section{The Multiple Features of Dams}

The obstruction of river flow and creation of artificial lakes through dam building provide a means to manage water resources. There are numerous existing dams in use. Some are small, while others are large and impressive.

A dam has multiple benefits, most of them which relate to water use in agriculture, energy, transportation. In brief, a dam can provide these functions:

- Regulation of water flow to prevent floods;

- Supply of water during drought. The water of the dam's reservoir, which accumulates during rain periods, is extracted or released for industry, households, and agriculture;

- Provision of clean and renewable energy by transferring water (hydro) power into electricity;

- Recreation or commercial use. The water reservoir created by dam's construction could be used for fisheries (sport or food source), and tourism (providing money for the service sector);

- Waterway transport. The raised level of the water from dam construction can improve conditions for navigation, and thus the dam could provide for a safer and a more efficient mode of transport; and

- The role of a bridge. The reinforced part of the dam can serve as infrastructure in future roadways.

A particular 'benefit' of dam building is one involving its use as a political weapon. For example, a country in the upper river basin could built a dam close to an adjoining country with riparian rights and choose to manipulate the river flow by either limiting flow during drought or by greatly enhancing flow to a level that would damage the lower riparian area during particularly important times, such as harvesting. These actions are possible scenarios that are likely to cause long-term friction between countries. Furthermore, large dams constructed to divert water from the natural drainage of rivers, can negatively influence biodiversity and change the distribution patterns of water in the basin, especially where inter-basin transfers are involved. As Shiva (2016) mentioned, this interference can generate conflict that easily escalates into disputes between states, especially where water stress becomes the everyday norm in the future.

There is considerable debate regarding a dam's usefulness. Much discussion hinges on the disadvantages relating to dam building. For example, locating dams on rivers that flow through more than one state's territory can create animosities between riparian states about water allocations. Maximum impact of this scenario arises where a state in the upper river reaches decides to build a dam and thus, gain power over other riparian states by way of controlling their water supply. One such case involves the region crossed by Tigris and Euphrates rivers where the Turkish state intends building more than 20 dams under the Turkish program known as 'GAP'. This action will undoubtedly affect Syrian and Iraq whose political survival depends heavily on water flow from these rivers. For Turkey, the dams in the south-eastern part of the country represent a means for political control over the Kurdish population, as well as Syria and Iraq. As emphasized by de Villiers (2000), dams mean power. However, such dam building will further complicate an already complex situation in this region of tension in the world.

Dam emigrants are another negative aspect caused by a dam's construction. Large dams not only disrupt natural ecosystems but also adversely affect human populations and thus have a social cost. Since 1949, China has relocated a total of at least 23 million people because of Chinese water projects. In summary, for more than sixty years in China each day some 1035 people have been forcibly moved for reasons of water projects' construction (Chellaney, 2013). A dam's construction demands concentrated effort from its inception to the last 'brick' installed, while rising water levels will flood large areas previously used for agriculture, transport, and industry. Forced mass migration is an everpresent element in these cases, especially where, on the upper side of the dam, populations existed prior to dam construction. Nonetheless, topography influences this aspect greatly, with low river banks 
providing a large land surface area for water coverage, while mountainous areas result in less land surface area being inundated, and (generally) fewer water emigrants.

In addition, Lei (2011) identifies the threat caused by the race to build dams. Lei maintains that while the race to build dams can amplify the already strained relationships among riparian states, overdamming can create direct damage: where several large dams located in a region trigger dam-induced earthquakes.

The costs and time needed for completing dams are high. They align with the dam's size. Even though the source of energy is inexpensive and renewable, being generated from flowing water, the costs for all materials and technical elements that transform water power into electricity (especially turbines and electric equipment), and their assembling, are enormous. It is important to note the contribution to cost involved with the expected time needed to complete a dam's construction and the daily high probability that a large dam's construction will run over budget and require a greater span of time than first calculated. However, when compared with large projects, the World Commission on Dams Report (2000) reveals that projects for dams with a height less than $30 \mathrm{~m}$ and a reservoir area less than $10 \mathrm{~km}^{2}$ tend to meet predicted targets and demonstrate less variability for major area development, such as irrigated areas and intense cropping.

The next point is dam's efficiency. Where it produces high energy with low investments and maintenance costs, the dam fits the category of an efficient project. This category is mostly influenced by the dam's emplacement and the area where it is located. Where the river has a natural pronounced declivity on the upper side of the dam, its capacity to generate power is greater than in the case where the declivity is small, and investment costs in both cases are possibly similar. This situation is especially observed with run-of-river hydroelectric systems.

Since rivers in mountains are relatively narrow in most cases, dams can be built in these areas to create artificial lakes, where water is captured and transported through tunnels to a hydropower plant at the base of the mountain. However, this use will likely threaten areas previously untouched by a human civilization and its potentially destructive effects. On the list of few advantages, in this case, is the possibility of a short electrical network that could connect (over short distances) hydropower with the needs of the military. Strategic energy and industry are best protected by nature, and mountains offer the ultimate shelter for these types of activities.

\section{The Momentum of a dam}

First, long before a dam is under construction, a political decision occurs at the highest level of the state overseeing the dam construction with full deliberation. That individual dam, where it comprises turbines, would become a hub in the national energy infrastructure, a part of that state's national energy capacity. That national energy capacity is decided upon at the highest political level and depends on many variables, some of them which are natural features while others are created. Natural variables are connected to the river's characteristics or potential to create artificial lakes, e.g. topography, geology, geography (physical, human, and economic), and other available energy resources at the national level, as well as existing resources in other countries and the prospective access to them.

In addition, a large part of the political decision is driven by fears as well as expected benefits over the long term. International context is an important factor that has a significant influence over this process. Present and expected global and regional contexts are both critical, but most crucial are the evolving relations among riparian states. Dam building in one country, similar to an arms race, can trigger a race to build dams in another within the same river basin. Expecting fossil fuel prices to rise (especially for natural gas), or worst, their fluctuation, and the likelihood of political dependence can greatly influence such decisions. Political dependence is especially the case where an upper riparian state manipulates river flow through dam building to affect the water allocation of downstream riparian countries and thus, their food production. Climate change is a current issue that needs greater consideration when a state analyzes its available solutions for future energy production, with waterstress adding complexity to its decisions.

As one can observe, for certain natural attributes (variables) there are superimposed human actions that are influenced by fear, constraints, and opportunities. At the same time, technological 
developments and new discoveries provide a rising the number of opportunities (e.g. offshore drilling or shale fossil fuels).

When a nation chooses a strategy to build dams and that state's national territory and rights allow this path, it means that this state has become aware of its natural potential, wants to use it for its wellbeing, has the will, determination, and access to the resources from the financial, technical, and human perspectives. However, the state also needs to be aware of its influence on the natural river flow, and the possible adverse effects that the state's actions could trigger for other riparian states as well as biodiversity. It could heighten tensions among riparian states. Nevertheless, where the decision to build a dam involves two or more countries from the same river basin, the dam could become a project to unite those interested states. Therefore, it could represent a starting point for more open political relations in the future. For this to happen, there must be a political will from the part of the states that are likely to be involved in such a project. They would need to understand that unilateral measures could only be a short-sighted solution, with long running deficiencies, while a long-term perspective with benefits for all riparian states would contribute to solving tension, and greatly improve international relations with dams, in this case, being the technical elements that sustain a broader process of fostering peace.

The political decision regarding a dam's construction involves three important elements:

1. Technical capability required to complete the project;

2. Managing resources for successful project end (human, financial, and logistical), and

3. Sustainable integration of the dam in a national (or regional) electricity grid and managing effects on the overall river basin, especially effects on downstream riparian states.

Technical capability can be considered from two angles: 1) original engineering techniques and methods, and 2) new chemical compounds that generate fresh opportunities for novel materials in dam construction. These apply to historical dams built to create water reservoirs and prevent disastrous effects of floods, as well as those of the last century that focus on energy production. Dams, energy, urbanization, and industrialization have become highly interconnected.

Mobilizing human resources needed for dam building is a highly complex activity. First, after the decision to build a dam, specialist teams need to be united under a collective umbrella.

These specialized teams are organized into different types of activities. One team will focus on economic-financial issues regarding the financial resources involved, compensation in case of expropriation, damping and efficiency of the dam, and its financial rate of return. Another team would exist for terrain, topography, environment, and geological issues to analyze the best place for the future dam, how to least disturb the environment through the dam construction, and to understand precipitation and the water flow regime during and after the dam construction. Another would cover technical issues, focusing on the best technologies and materials to be used, the best location for the dam, considering the type and shape of the dam, and ultimate features such as height, the number of turbines, and connection to the national or regional electricity grid. Another team would cover legal issues around the application of pre-existing laws and conventions during the dam construction and its exploitation, compensations paid to those affected by the dam construction, or legislation to be applied after dam completion.

The legal arm is of utmost importance where a dam is built on an international river (which could be an international waterway) and where two or more countries participate in the dam project. It will be the main team, which will work on details regarding the construction of the 'legal' bridge involving international accords and conventions that precede the technical construction of the dam. Furthermore, apportioning the future electricity production, adjustments to borders in the case of dams being located on a river that acts as a border, amendments because of water level rises, participant costs and burdens and their apportionment, solutions for unforeseen events, as well as other legal matters, are the focus of domestic and international law specialists.

Where two countries unite to build a dam, representatives from both countries are grouped into different national teams (specializing in economic-financial, technical, technical terrain documentation, and legal issues). These groups form the pillars of the one unique mixed international team (or international commission) that unites specialists under individual aspects of the one umbrella. 
International context is critical in the context of there being a commonality in building a dam by two or more countries. In this case, negotiations precede the conventions, agreement signature, and ratification, as legal basis for the constructing of the dam as a joint endeavor. In the future, the international context may be influenced by climate change and water shortage considerations. With this in mind, all riparian states would need to be involved in decisions. However, such actions and decisions may be affected by water nationalism. The first situation could bring long-term benefits for riparian states, whereas the second, only deep distrust and conflict.

In the first case, negotiations with the objective of innovation are needed. As Ikle (1964) mentioned, the main subject of innovative negotiations pertains to creating new institutions. Since two countries decide to unite to build a dam, the creation of a mixed specialist team or teams is a natural prerequisite. This progression points to the need for innovative negotiations where two countries unite with the common aim of constructing a dam. At the same time, these negotiations are intended, as Malita (2007) mentioned, to exploit common interests. Countries determined to build the dam together will gain net benefits in the field of energy independence, low pollution, and greater water allocation for agriculture, tourism, and fishing, as well as possible improved navigational conditions. Where the river being dammed crosses more than two countries, all riparian states could benefit. All would have lower navigational costs and trade could be stimulated using the river, meaning lower congestion and transportation risks for land transport, coupled with lower emissions, lower pollution, and greater mobility and integration at the river basin level.

However, to achieve this outcome, an international system for the transnational river is required beforehand. This system would need to be under a special umbrella and cover all bi- and multilateral negotiations including those for dam building and involving all riparian countries. For such a regime to operate smoothly, a lengthy span of time would be required.

The best example of a transnational case involves the Danube River, which flows through ten countries, making it one of the most international rivers in the world. The Iron Gate System of dams involves a gorge located on the Danube on the ex-Yugoslavian-Romanian border. It is noteworthy that negotiations for this dam building had a very technical character, meaning a high degree of complexity and requiring the participation of several specialists over a long period. As well, the diversity of issues to be solved demanded a series of parallel negotiations.

Moreover, this is an ever-present peculiarity of dam construction. However, the building of a large dam by a nation on its own is a sign of that nation's emergence and desire to affirm itself on the international stage. It could be proof of its technical, financial, engineering, management, and human competencies, and its determination to modernize. However, it could also denote a sign of its desire to manipulate the environment. Added to this list is energy independence, as well as climate change and water shortage motivations, and intelligent water management, which will mark the agenda of the state that modernizes its existing or future dams.

Needless to say, a dam can be constructed as a political weapon, aiming at extracting unusual behaviors from other riparian states. through the creation of reservoirs in their territory, an upstream riparian state can reduce the river flow reaching countries in the lower river basin that greatly depend (especially for agriculture and urbanization) on that river flow. The two greatest examples of this occur with Turkey and China. These countries view water on their territory as a natural right to use as they deem fit, without much concern for other riparian countries along the same river. This creates concern and increasing distrust between the countries involved. Not only are they unaware of the environmental impact of such projects and the social costs of relocating people, but they also contribute to future instability in transnational river basins. Hence, water could become a trigger for conflict, and not an integrative natural resource for all countries and people to share in their water.

\section{Conclusion}

Life is impossible without water. For this reason, water and civilization are inseparable. If in the preindustrial era people had been unaware of the sustainable economy concept, using nature without harming such, then the Industrial revolution has changed this. Humans have started to view nature and natural resources as fully and readily exploitable elements, without much concern about possible future evolution. However, the recent decades have proved this path to be inappropriate. As a natural resource, water has been used inappropriately also; and the damming of rivers has occurred without 
much concern for the effect on the environment, or on populations being displaced. Dams were viewed as technical faculties that proved a state's political clout and became known as instruments of social modernization.

New developments and recent evolution have changed this view; water has become a natural resource under threat, marked by a lower quality and quantity partially attributed to environmental change and partly to pressure due to a more populous, industrialized, and urbanized world. Water crisis and associated food emergencies are future problems that will plague humans. Water is becoming a scarce resource and water stress will crucially influence future developments.

In this context, dams could be connected to water nationalism, becoming instruments of political control over other countries and societies and rising instability in international river basins. Alternatively, they could become technical instruments built by two or more riparian states in unison and facilitating cooperation among riparian states. This latter scenario would contribute to a deeper regional integration of societies and economies. The first setting would complicate further an already conflicted world; the second would contribute to greater international stability and multilateral gains. Humans are at historical crossroad and their future will be partially influenced by decisions about water use, and the integration of dams into this context.

\section{References}

Chellaney, B. (2013). Water, Peace, and War. Confronting the Global Water Crisis. Lanham, Boulder, New York, Toronto, Plymouth UK: Rowman \& Littlefield Publishers, Inc.

Dams and Development. A New Framework for Decision-Making, The Report of the World Commission on Dams. (2000). London and Sterling: Earthscan Publications Ltd.

de Villiers, Marq. (2000). Water: The Fate of Our Most Precious Resource. New York: Houghton Mifflin.

Ikle, F. C. (1964). How Nations Negotiate. New York: Harper \& Row, Publishers.

Lei, X. (2011). Possible Roles of the Zipingpu Reservoir in Triggering the 2008 Wenchuan Earthquake. Journal of Asian Earth Sciences, 40(4), 844-854.

Malita, M. (2007). Jocuri pe scena lumii. Conflicte, negocieri, diplomatie. Bucuresti: Editura CH Beck.

Shiva, V. (2016). Water Wars. Privatization, Pollution, and Profit. Berkeley, California: North Atlantic Books. 